\title{
Structures of a Life-Work: A Reconstruction of the Oeuvre of Thomas Luckmann
}

\author{
Jochen Dreher ${ }^{1}$ Andreas Göttlich ${ }^{1}$
}

The following is a transcript of an interview with Thomas Luckmann which was conducted in two sessions on the 22nd and 23rd of June 2015 at his home in Kärnten, Austria. It opens up a retrospective on the widely spread scientific life work of the famous sociologist, who has left impressive marks on the academic field. He is specifically known for his renewal of the field of sociology of knowledge and on this basis the establishment of a general sociological theory. Monographs like The Social Construction of Reality (together with Peter L. Berger), The Invisible Religion, or The Structures of the Life-World (with Alfred Schutz) have each wielded significant influence and are till this day standard literature in their particular disciplines.

The questions were compiled and posed by Jochen Dreher and Andreas Göttlich from the Social Science Archive Konstanz, at the University of Konstanz, where Thomas Luckmann's scientific materials are stored. For the sake of clarity, the transcript is subdivided into five chapters, each of them dealing with a specific theoretical and/or empirical field: (1) Phenomenology, (2) Sociology of Knowledge, (3) Theory of Action, (4) Sociology of Religion, (5) Language, Communication, and Genre Analysis. The transcript was revised post hoc by the interviewers as well as by Thomas Luckmann himself. In order to preserve the impression of a spoken conversation, only plain mistakes were corrected and some redundant phrases were omitted. Italics indicate emphasized words as well as book titles.

We would like to thank Maria Sophia Putz und Daniel Kleboth for their intense work on the interview transcript.

Jochen Dreher

jochen.dreher@uni-konstanz.de

Andreas Göttlich

andreas.goettlich@uni-konstanz.de

$1 \quad$ Konstanz, Germany 


\section{Introduction}

INTERVIEWERS: Professor Luckmann, with regard to your academic socialization, it is apparent how many different disciplines you studied: linguistics, psychology, Egyptology, philology, philosophy, history, and more. In the end you decided to become a sociologist. Why?

LUCKMANN: First of all I was not academically socialized. That's sociological jargon that I don't like personally. I was trained academically in various disciplines. Even that is not quite correct, I wasn't trained in many disciplines, I studied a bit here, a bit there. My main interest at that time was in linguistics, history and literature, and philosophy of course. So the other disciplines were frosting on the cake that I didn't pursue seriously later.

Now, the question was, why did I shift to sociology? Why did I decide to do sociology? I didn't. I decided to do philosophy seriously. When I came to the United States and started studying at the Graduate Faculty of the New School, I studied philosophy. And my second subject, partly because of my teachers, was sociology. These were Albert Salomon and particularly Alfred Schutz. Alfred Schutz had a double appointment in philosophy and sociology. But my own main subject was philosophy. I studied with Karl Löwith who was at the New School for a while, and started my master's thesis with him. So at that time I didn't decide to do sociology, except as a second subject because it was close to philosophy as it was taught in the New School at that time.

Löwith left before I finished my master's thesis which was on Albert Camus. It's called "The Limits of Insurrection". At that time I was working at various odd jobs. So was my wife. We had two children and I was looking for a job. That same time I planned to continue to a Ph.D. I had taken a course or two courses with Carl Mayer, the sociologist of religion, who planned a major investigation of the churches in Germany after World War II. He got substantial financing for it. He hired three assistants, and one of them was Peter Berger, with whom I became friends, in a class of Löwith, incidentally. That was at the beginning of the Korean War. Berger was drafted into the army. I wasn't yet an American citizen at that time. He was. So, Carl Mayer was looking desperately for someone who had at least an inkling of the sociology of religion and who spoke German. So I got Berger's job. I decided to use part of my empirical field work in Germany for a dissertation in sociology. I kept philosophy as my minor subject but I shifted to sociology for my Ph.D. So I never decided outright that sociology was the field that I wanted to study, I somehow slithered into it.

INTERVIEWERS: How would you describe your major fields of research?

LUCKMANN: My major fields of thought or my major fields of research?

INTERVIEWERS: Both would be important for us.

LUCKMANN: Well, let's start with thought. Through Schutz I encountered phenomenology. I hadn't read Husserl before I met Schutz. I would say that I am or was a trained phenomenologist, which few people who describe themselves as phenomenologists are, if I may add this bitter note. Dorion Cairns was one of my teachers in phenomenology, so I think I had decent training in the field. That is not a 
field of research, that's a field of analysis or philosophical description. Phenomenology was one area of thinking that I became not only interested in, but pretty seriously involved in.

As for sociology proper: As I said, I got into sociology by an accident, getting a job on Carl Mayer's research project_-it was funded by the Rockefeller Foundation incidentally. I did become seriously interested in sociology because most of philosophy, except for phenomenology, to me, in my arrogance of a young student, treated boring things, either the history of philosophy, which is a very legitimate subject, but didn't interest me, or else so-called linguistic analysis which wasn't a genuinely linguistic analysis. It seemed to me slowly-maybe I just convinced myself because I already had a Ph.D. in sociology-that sociology answered more important questions or at least asked the more important questions than philosophy at that particular time in that particular situation.

In sociology, I was influenced by my teachers: on the borderline of philosophy Alfred Schutz, of course, Albert Salomon, Carl Mayer in sociology of religion, but indirectly by Max Weber and Emile Durkheim - a very peculiar combination, two people who never took note of one another-and by the Durkheim school of Halbwachs in particular, but also by others. So that was the preparation as it were for my collaboration with Berger on The Social Construction of Reality. All that is not research. It is, well, thinking, formulating, perhaps one can even call it a form of analysis, but not of empirical analysis. That came quite a bit later. No, that came early on the Mayer project. That was conventional field work, interviewing, even questionnaires, but mainly a kind of ethnographic field work. This led to my dissertation. But I was dissatisfied with the methods and I didn't do that kind of work later.

Then, for a while, I didn't do anything that could be called empirical analysis. I wrote on various problems and I read the literature on that, I read the studies for example of social class, social stratification, social mobility, things of that sort, where I didn't do any empirical work of my own, using the work of others for analysis.

I was always interested in language, starting with the philosophy of language, and when I landed in sociology, in the sociology of language. Now the state of affairs in the sociology of language in the early 50's was dismal. Not only in the United States, in France also. But again I didn't do any empirical analysis in this field at that time. I wrote a handbook article in German for the Handbook of Empirical Social Research edited by René König. I hadn't really taken note of the ethnography of speaking. I had taken note of ethnomethodology, but not very positively. Conversational analysis then showed me what can be done in detailed empirical investigations of communicative processes. Although I had read Garfinkel before and knew Garfinkel personally, it wasn't my line of thinking, to put it mildly. But then I read some conversational analysis, in particular when I met Jörg Bergmann, who became my assistant at one time at the University of Konstanz. He was a trained conversational analyst. I thought that this was a line of analysis which would show-I put it now in a rather stereotypical way-how communicative processes build the foundations of The Social Construction of Reality. My interest in empirical studies started with the theoretical interest that is articulated in the book by Berger 
and me. It started that way, but it led me then later to slightly different theories. The method of conversational analysis was the starting point. I didn't like its theoretical underpinning. Sacks' references to Wittgenstein for example didn't seem to me very pertinent. There are other reasons why I thought the theoretical underpinnings of conversational analysis were not sufficient, not adequate. Then I started thinking back on my own reading and thinking in the philosophy of language, the sociology of language, and discovered the ethnography of speaking. I discovered it just as Columbus discovered America, that is, there were people there before who knew where it was. But for me it was new. The work of John Gumperz for example and others.

The reason, the motive behind that was the interest in how things work en detail now. Which processes lead to the consolidation of something like reality in general and social reality in particular? So the push came from conversational analysis, especially Sacks, but also others that I read later, and on a personal level from Jörg Bergmann. And then came a different line of thought that I took up in that connection, genre analysis. I had contact with some literary scholars in Konstanz, and saw and heard that what was a classical analytic category in literary studies, genre, was not cherished by them who were constructing a new literary theory. There were endless discussions of whether they are real categories. It reminds me of debates centering the one thing that I don't think is adequate in Weber's thought, the "ideal type". I thought the concept could be interpreted as corresponding to what Durkheim calls "institution". Social fact defined as extériorité contrainte. Genre exercises a certain degree of constraint, and it helps solving problems. In this case not of social life in general, but of communication. I thought, and still think, the category of genre that I introduced into sociology then, with the help of others, especially Bergmann. Knoblauch, Günthner, and others joined the cavalcade. Genre turned out to be a useful term, an analytic category to describe those communicative processes which are not just spontaneous and disorganized-except organized by language of course and organized by social relations. All linguistic communication is organized. It's language that exercises a certain amount of constraint if you want to be understood. There are some social constraints in communicative processes. In a rigid class society for example there are restraints of particular kinds in the communication of a member of class $A$ to a member of class B and vice versa and they're asymmetrical in that case. But those are not yet genres, you can still choose freely from the code and freely from the language according to your interactional intention. Genres on the other hand serve as models that select from both codes, from the linguistic and the social interactional code, select in such a way that certain constraints are given.

Alright, I got carried away. My major field of research after that early conventional field work was in the analysis of communicative processes. I indicated how I got into that and why I thought this kind of process analysis was useful. I introduced the category of genre as a problem-solving model, as a quasi-institution for communicative interaction. The degree of constraint differs, some genres must be taken up in some social situations and you have no choice. In others, whether you tell a joke or not tell a joke, that's normally up to you, unless you are at table after a dinner, a speaker in a particular kind of milieu, then you need not to tell jokes. In the 
last decades, after my retirement, I haven't done any other empirical research except of that kind, usually with colleagues. I think empirical work of that kind is best done by teamwork. One is often misled by one's own first interpretation. It is good to have someone else to offer another one. Now that kind of empirical research requires in my mind an advocatus diaboli. Or to put it more conventionally, requires attempts at disproof or attempts of correction. And then you have to start talking to the other person in the project or the two other persons or even better three other persons, and then you slowly might get approximately what really happened. In this respect my empirical research was usually with others, first and foremost with Jörg Bergmann, then with Susanne Günthner, Hubert Knoblauch, Angela Keppler, Gabriela Christmann, also with some others, with Per Linell, a Swedish linguist, for example - that was slightly different in theoretical background on asymmetries in dialogue, that you don't work alone. Thinking is best when alone, and occasionally in dialogue. But empirical research requires a different kind of procedure.

INTERVIEWERS: When you talk of correction and group analysis, I sense some similarity to the method of sequential analysis, like in the work of Oevermann or Soeffner.

LUCKMANN: Conversational analysis is sequential analysis and genre analysis is sequential analysis. Oevermann's is sequential analysis of a quite different kind. Oevermann and I were good friends, but I would say that he knows in advance what's in the data because he has a sort of theory, a structural theory, and that to my mind, is the wrong approach. But it is sequential analysis of a different kind. Genre analysis is closer to conversational analysis in its method, not in its theoretical interests and underpinnings, than is Oevermann's work. There are some developments from conversational analysis which are not classical conversational analysis, but still sequential analysis. And I think that one can learn from one another quite a bit. One can even learn from Oevermann.

\section{Phenomenology}

INTERVIEWERS: Why did you introduce the term "proto-sociology" to describe the epistemological foundations of the social sciences, a term Alfred Schutz for example did not use?

LUCKMANN: Schutz didn't use it, but Schutz, I think, was the first practicioner of proto-sociology. Schutz was a philosopher, of course, a phenomenologist. But what he did in sociology was not sociology in the narrower sense of the term. It was not empirical analysis. He used a different method, a phenomenological method. What he was doing and what some other people-me included-were doing was proto-sociology. That is, a phenomenological analysis of the structures of everydaylife.

How do you compare interaction among Andaman islanders with that of rockers in Los Angeles? Either they are not comparable, as many people in despair have said: everything is its own world. Now that's a kind of anthropology that I can't share; we are all human beings, we all have the same evolutionary heritage, we even look sort of similar and probably we feel pain in a similar way etc. There is a 
conditia humana, to use Plessner's term, which means that there must be a possibility both of communication and of comparison. If Robinson and Friday start talking to each other, they are quite different, they are a better example than the cultural anthropologists who say that the world of the Australian Aborigines is quite different, incommunicable_or in literary terms: altérité, total altérité. Non-sense! It's difficult, of course, but it's difficult to understand my aunt. I find it very difficult to understand some sociologists for example, of my own culture, speaking one of my languages, and occasionally I don't even want to understand them. But in principle, it's possible. If one sociologist can understand another sociologist, a Maya Indian from Yucatan can understand a Norwegian fisherman. Not easy, takes a while. Took Robinson and Friday a while also. But in what categories can one establish the possibility of communication and comparison? I think that's what a proto-sociology does. This might have been Schutz' intention also, but as far as I know he never stated it in this terms.

INTERVIEWERS: And you actually adapted this concept from your colleague, the philosopher Janich, who spoke about proto-physics, is that right?

LUCKMANN: He was a physicist philosopher at the University of Konstanz in my early days there. He used the term for a philosophy of physics, which was not physics, but an attempt to establish the presuppositions of doing physics. He called it proto-physics. I thought that was a good term. I knew Janich personally and I read one of his books, with some difficulty, and adopted the term, as I use genre, an old established term. Thanks for reminding me. In the cause of years I had almost forgotten.

INTERVIEWERS: When you look at the current state of sociology, do you think that the intention of Schutz and yourself of establishing a solid foundation for social scientific research, and thus improving it, succeeded?

LUCKMANN: I have no idea. I haven't been reading much sociology for the past 15 years or so. I don't know what's going on in sociology in the United States, in sociology in Germany, in sociology here, Norway. So I have no firm basis for answering your question. I leave it at that, I don't know. I have an idea though. I have a notion that it is practiced, not by a small clique, but nevertheless by a minority. I find that, for example, categories from The Social Construction of Reality, which were adopted from elsewhere, are used by many people who write books: "The Social Construction of this or that". They acknowledge that the categories are taken from Berger and Luckmann. But they are rarely convincingly connected to the attempted empirical analysis.

The better example is Marx. In communist societies, scholars had to quote Marx for the first five pages. And then they did something different. Now that's what they did, sort of, with Parsons and structural functionalism, and many are doing this also with the categories of The Social Construction of Reality. It's an acceptable preamble to one's own work. But it doesn't influence the work very closely. I've come across some good and to me impressive continuations. But I remember better attempts that failed. Books were published and there is a lot of Berger and Luckmann in them, in the footnotes, and there is quite a bit of their categories, but when it comes to the analysis itself, there doesn't seem to be too much of a connection. I think that I did one good thing by using genre analysis as an attempt to 
show how the general categories work-I don't think in our analyses of communicative processes, of moral communication, of reconstructive genres, etc., we ever used the terms exteriorization, internalization, and objectivation. But they are in the spirit of The Social Construction of Reality. And many other things are not. They are doing an empirical part on this or that and there is almost no connection to the categories from The Social Construction of Reality.

I think the more important thing is that Schutz is widely quoted, not by mainstream sociologists, but by many academic minorities in many countries. Schutz is an important figure on that level. Not quite as Max Weber who was important beyond a narrower school of thought and influenced many others, including Parsons of course. I wouldn't say that this is quite the case with Schutz, but he still is a very, very important figure in the development of modern social thought, including sociology and social philosophy. Some also use some of Schutz' thought, but many leave it at quoting, at references to or paraphrases of Schutz.

INTERVIEWERS: The project of describing the "structures of the life-world" is meant as an a priori theory.

LUCKMANN: Is it?

INTERVIEWERS: You wouldn't agree?

LUCKMANN: No. But I have no serious objection because perhaps I know what you mean. It is not a priori in the Kantian sense. It is distantly related to it. I wouldn't use the term, but I can accept it. No, I don't accept it, but I can see why you can use it in relation to what I think Schutz tried to do in the Structures of the Life-World and which I much later called proto-sociology. It is a priori in the sense that it doesn't use momentary, historical, culturally specific processes that are turned by a sociologist into facts. I still don't like the term "a priori". It starts with Descartes, as Husserl in his Cartesian lectures showed, and the point is that one has a firm basis of thought if one attends to it carefully. And then Husserl introduces the reductions to come to the bare bones of a process, to the constitutive elements. Since this is so different in method, it doesn't rely on public facts. This is what I tried to say before. It relies on, one can say introspection. No, that's a bad term, that's a psychological term. I think I'd rather say, in conventional sociological language, attending to with a sharpened eye and ear to the stream of consciousness and to what crystallizes in the stream of consciousness. A core-element is an experience, eventually an interactional experience, although the shift from the egological to the intersubjective level is not that easy, theoretically or philosophically, for Husserl, for Schutz and for others.

INTERVIEWERS: Ok, I reformulate the question. Let's say that the theory of the structures of the life-world is not couched in empirical terms, let's formulate it this way?

LUCKMANN: Does not rely on public facts. It does presuppose a sort of anthropology though, as phenomenology in general does. And that Schutz came to see himself, not perhaps at the beginning, I don't see much of that in the Sinnhafte Aufbau, of an awareness of anthropological preconditions. But later he spoke of it himself. Now in German one uses the term "Wende" for all sorts of things. There is an anthropological Wende, a shift, in his thinking, an anthropological shift. 
INTERVIEWERS: Now the question is, if the theory of the structures of the lifeworld does not refer to "momentary, historical, culturally specific processes," to use your own words, do you then think that the structures of the life-world may change in the historical process?

LUCKMANN: No. If they do then they are worthless. But that's the anthropological presupposition, that an Australian Aborigine and I have a lot in common, and probably a Neandertal and I have a lot in common. What we have in common is everyday-experience. What we have in common is intersubjectivity, interaction. What we have in common are bodies, that can fight, that can love, that can hurt, that can please. I'm convinced that a Neandertal, although a different species, is not that far away, but an Australian Aborigine very definitely isn't. And if the structures of the life-world do not help as a proto-sociology for an analysis of Australian Aboriginal culture, at least in principle, for a comparison with the everyday-life world of a Norwegian fisherman, then they are worthless, then throw them away. Then say they are not comparable at all, they are different cultures, and more than that, different worlds. I think different cultures are variants of the same world that can be analyzed phenomenologically. The attempt to detect anthropological base elements has been done elsewhere, but in my recollection hasn't been particularly successful. That is to say, a collection of terms from fifty languages for the presumably same kind of experience, to see whether it really is the same kind of experience. There was a Yale project on that many years ago, that was an empirical attempt to establish constitutive elements in all cultures, on the linguistic level, on the interactional level, and so forth. I'm not saying that that's impossible, but I wouldn't know how to do it.

INTERVIEWERS: You used Musil's concept of "parallel action" to describe a combination of phenomenological and social scientific research. And you applied this method to describe the boundaries of the social world. Would you say that there is a general potential of this method of "parallel action" and which particular areas of research could profit from it?

LUCKMANN: Let us go slowly. You may have to repeat parts of the question if I get lost in the first half of the answer. The first part of the answer is that "Parallelaktion," "parallel action" is for Musil, of course, something quite different. This is a kind of scholarly joke to use that in a totally different field for a totally different purpose. I won't go back to Musil, whoever is interested either knows it or he can look it up. The way I used the term "parallel action" in that article "Boundaries of the Social World" is on the one hand to show how close to the concrete historical social facts, as formulated, discovered, observed by an ethnologist, one can get by phenomenological analysis of the structures of the everyday and the non-everyday-world. If I remember correctly, the motive for that was a certain degree of annoyance-many, many, many decades ago-at the assumption that animism is a pathology. Or a very early, totally incomprehensible, in general rather silly way of looking at the world. Totemism, pretty much the same. That was before Lévi-Strauss. But reading some work on totemism and on animism, I thought this approach can't explain the common element in all that, in our way of looking at the extraordinary levels of reality, beyond everyday reality. And why is it that for Husserl—-that was a sub-thought, as it were, not directly connected to that- 
why is it that in Husserl's analysis what is presupposed is a concrete empirical human ego. Behind all the reductions nothing human remains, unless we know from a different source that it's human. But the reduction doesn't show it, it shows processes of a peculiar kind, whether we share them with a bird or not is another question. I suspect not, but that's an empirical, not a philosophical answer.

So there were various motives for starting on that paper, of that line of thought. One was to show how far phenomenological analysis can show the common elements, the common constitutive elements in the experience of the ordinary, the extra-ordinary, of what is human and what is non-human. And set this in a parallel action, step by step, to what the ethnographers have said about it and written about it. For example for the Dobuans, some human beings are not really human beings, but yams are human beings. The ethnographer asked them-I don't recall this in detail: "Why do you say that they are human beings? Have you seen them walk? You walk, I walk; we are human beings". "They walk" they said, "yams walk, yes". "Have you seen them walk?" "No I haven't. But yams only walk at night. You can't see them walk at night".

So this level of apperception, in classical terms, of the world, of certain levels of reality and corresponding categorizations of reality-after all this is one of the elementary categorizations: social being, not social being; for us: human, non-human. And I found that I came quite a long way with this parallel action approach. This is one of my two or three phenomenological papers. The others are in sociology, or whatever they are, they are not phenomenology. This one I like myself, incidentally, after all these years. I remember writing it with some sort of intellectual pleasure. Did I answer the question or are there some parts of it that I didn't?

INTERVIEWERS: Well, this was, let's say, two thirds of the question ...

LUCKMANN: Well the first third was merely "parallel action" in Musil. It refers of course to the celebration of the emperor's birthday or something like that which the Prussians or rather Germans planned, and the Austrians then decide they ought to do it, too.

INTERVIEWERS: I think the emperor dies before they can finish the "parallel action". Now, the question would be then, going on from this specific article, where the topic was the boundaries of the social world: Would you say that there is a general potential of this method? Could it be used with reference to other fields of research?

LUCKMANN: I think so. Why not? I mean in principle yes, for example to temporal and spatial description. I consider this a better way to look at empirical things with some phenomenological knowledge of the structures that are presupposed in concrete empirical facts. Concrete empirical facts are reduced in the phenomenological sense, but you can travel from the one to the other in either direction. In "The Boundaries of the Social World" they traveled in one direction. And in another analysis they might travel back the other way. But I think that the question of the boundaries of the social world is not the only one. In another halfphenomenological, also "Parallelaktion" type of paper of mine on the constitution of personal identity, I jumped back and forth between phenomenological analysis of a roughly Cooley-like approach and evolutionary findings in human biology. That is "Parallelaktion" also. I found it helpful. I found it useful and I'm still not convinced it cannot be useful for others. But the precondition is that these are trained 
phenomenologists and have some knowledge of cultural or social anthropology and philosophical anthropology, Plessner, etc.

INTERVIEWERS: In which way were your studies in sociology of knowledge, theory of action, sociology of religion and language, communication and genre analysis influenced by the phenomenological paradigm?

LUCKMANN: Well, let's start with the sociology of knowledge. In Schutz' seminars and elsewhere we read the classical sociology of knowledge, that is, Scheler and Mannheim in particular. I hadn't read either of them before. I had read Marx before, some Marx, the anthropological writings in particular, and they are relevant for that. But I came to read more mainly through Schutz' seminars. Perhaps Berger might have been reading more in the area than I did, earlier and independently of Schutz' seminars. When we got together, he and I, we called our project an "essay in the sociology of knowledge," but of course we did not conceive it narrowly. We didn't intend to start a new grand, grand theory however, as every fifth sociologist nowadays does. That was not our intention and it wasn't meant as an attack on structural functionalism either, although we thought that this theory was inadequate as a basis for sociological and social theory in general. And we thought that the classics, in particular Durkheim, Max Weber, and Marx, did it better, especially if combined with American pragmatism, Mead, and Cooley. I don't think we spoke about it. We probably thought both along similar lines that this might be a fairly good beginning for a general social theory, that is, a continuation of the classics, but not in the form of structural functionalism.

INTERVIEWERS: Just in general, when you think about a different area of research ...

LUCKMANN: Ah yeah, that was sociology of knowledge.

INTERVIEWERS: ... was there a general impact of phenomenology?

LUCKMANN: Phenomenology had an indirect impact. Not only through Schutz' seminars, but through Schutz' work, that wasn't a book at that time, but various articles that led to The Structures of the Life-World. One chapter in The Social Construction of Reality is a condensation of some parts of The Structures of the Life-World, in the chapters on knowledge, the subjective constitution of knowledge and the social construction of knowledge-I forgot what exactly the titles are. And the second one is not quite by Schutz, I will immodestly say that this is continuation of Schutz by me. Most of the book is of course Schutz.

For the sociology of religion rather not. For my way of thinking in that area, Durkheim was the most important source, and post festum-I discovered him too late, but he would have been an influence-Robertson Smith, the semitologist. A friend of Frazer, acquaintance, teacher perhaps, who wrote The Golden Bough. Robertson Smith I should have read 50 years ago. He wrote on the religion of the Southern Semites, the Arabs. Well, the book's title is The Religion of the Semites, but it's mainly the Southern Arabs rather than Phoenicians and Israelites for example. That was retro-active inspiration.

INTERVIEWERS: And to speak of theory of action?

LUCKMANN: Oh-in my book-that was proto-sociology. I haven't done any empirical analysis of interaction in the sense the term is used nowadays, except of 
communicative interaction. But that is of course an essential form of interaction in all societies, not only human ones.

INTERVIEWERS: Would you say that there was a phenomenological impact on your thinking about communication?

LUCKMANN: Well, in my own personal development, I went from Schutz to Husserl. Husserl was interpreted for me, analyzed, and presented to me and taught, taught by Dorion Cairns, and by reading Gurwitsch in addition to Schutz. Cairns was an excellent teacher of phenomenology. And Gurwitsch was a very original phenomenologist. But by way of direct, as it were more intimate influence, it was Schutz.

The question was what? About the impact you said, influence, from phenomenology to the structures of the life-world, to the social construction of reality, to genre analysis. That seems to me, in retrospect, a fairly logical progression. Less accidental than most of my life. So in sociology of religion no, in communicative interaction analysis yes. But by intermediate steps, as it were. It was not protosociology what we were doing. It is based on proto-sociology. Yet if you ask Bergmann or any of the other associates, I think they would be indifferent to the fact that in my mind this is based on proto-sociology.

\section{Sociology of Knowledge}

INTERVIEWERS: Our next topic would be sociology of knowledge and the first question is: Your and Peter Berger's famous book The Social Construction of Reality is classified by the subtitle as A Treatise in the Sociology of Knowledge, yet is commonly interpreted as a general sociological theory. Does this coincide with yours and Berger's original intentions?

LUCKMANN: We knew what we wanted to write in the book. So that, the intention about the content was clear. How, in which direction we wished to influence sociological thinking? I don't think we had grand ambitions at that time. But if it is generally taken as an essay in general sociology or general sociological theory that corresponds to my present understanding and probably Berger's also and is not that far off from what we thought at that time. It has something to do with the sociology of knowledge, with an expansion of the classical and traditional sociology of knowledge in the direction of a general social theory. So it's not mislabeling, but it doesn't cover the full attempt that we made in that book. If it is interpreted as general theory, that's fine with me. I never did anything in the sociology of knowledge in the traditional sense.

On the one hand, yes, in my work along Schutz' lines, in the Structures and later after the Structures, but these were not empirical studies, such as sociologists of knowledge did at that time or a little bit later, to study science. A sociology of knowledge as sociology of science, but that was not my own, this was work of other people, and they were not influenced at all or only mildly by Berger's and my book.

INTERVIEWERS: Why did you and Peter Berger decide to reformulate the classical sociology of knowledge? 
LUCKMANN: Well, that's a sort of over-psychologizing question. For us it was not a matter of decision. In the strict sense of the term, I can decide to have red wine or white wine with dinner. That's a sort of decision which is embedded in the context of what kind of dinner I will have and how much experience I have with different sorts of wine. Those are decisions, everyday decisions. I think in science and generally in scholarship it is different, unless the decisions are opportunistic, that is to say, I have to get a Ph.D. or write a master's thesis for a particular committee. I decide to write on a topic and write in a fashion that increases the chances of the dissertation to pass. Those are decisions then, "Choosing among Projects of Action," to quote Schutz' title of a very interesting paper.

As for the question "What we decided"-we didn't decide very much except the general framework and then went on step by step. The general framework was taking up the classics. On the whole I think to this day, there isn't much theoretical advance, there's much more knowledge, but there isn't much theoretical advance beyond Max Weber and Durkheim and within limits Marx. To use them, now I'm quoting Merton, who is quoting Sterne, "we are standing on the shoulders of giants". Why not acknowledge this and really look, standing on, sitting on the shoulders of giants.

INTERVIEWERS: And yet you felt the need to go beyond classical thinkers like Mannheim and Scheler, for example?

LUCKMANN: Oh, in the sociology of knowledge definitely. I think they were limited to the kind of knowledge that is fully articulated, theoretized or ideologized, or both, as in the case of Mannheim. And there's an ontological component and interest in the classical sociology of knowledge that is to say: what hides behind knowledge. That was not our interest at all.

INTERVIEWERS: And would you say that you tried to establish a foundation for a sociology of knowledge, using philosophical anthropology and phenomenology, to get rid of the materialistic basis authors like Mannheim were applying?

LUCKMANN: Well, Mannheim was not a materialist, even Marx in his anthropological writings is not a materialist, whatever you understand by the term materialism, but they were ontologically interested in a different way and in a more traditional way than Berger and I. If we were ontologically interested at all, then this was related to the acceptance and adaptation of a certain anthropological philosophy, in particular Plessner. But that came partly after we had already conceived of the book and written most of the book. My own encounter with Plessner was in 1963 when he got the Theodor Heuss Professorship at the Graduate Faculty of the New School. I had read one little thing - the Conditio humana-one of the best that he wrote and I never really managed to get through his major work Die Stufen des Organischen und der Mensch. I don't know how many volumes I started at the beginning and looked at the end and then sneaked through the middle, but I can't say that I read this seriously, but I read several other things by him. As I said, in 1963 I met him personally at the New School and he agreed to write the introduction to the German edition of The Social Construction, which was translated by his wife. But I can't recall that there was any direct anthropological interest from that particular side at the writing, at the conception and the main part of the 
execution of The Social Construction of Reality. My memories are not that good about the nuances of thinking at that time, but I think I can say that much.

INTERVIEWERS: Since your work The Social Construction of Reality was published in 1966, the concept of knowledge has been considerably broadened within the sociological discipline. Polanyi for example introduced the term "tacit knowledge," Bourdieu included bodily incorporated knowledge in his concept of "habitus". What do you think about this development?

LUCKMANN: Fine. Bourdieu's work is certainly consistent with much of our thinking. I don't particularly appreciate his concept of "habitus," partly because of the word that he uses for the category, partly also because of the category itself. His work is quite interesting, definitely. Polanyi I read once and I soon forgot about "tacit knowledge".

INTERVIEWERS: One of the frequently repeated criticisms towards the Social Construction of Reality is related to an alleged oblivion of power. How would you react to this criticism?

LUCKMANN: Nuts! That's all.

INTERVIEWERS: So, what would be the status in your opinion of the power concept in your book?

LUCKMANN: The status? No particular status. Power is a category which in sociology was particularly articulated by Max Weber. Both Berger and I are Weberians from way back, but The Social Construction of Reality doesn't deal with that specific form of interaction, institutionalization, and interactional results that are caught or defined by the concept of power which is a rather loose concept anyway, even in Weber-but much more so in others.

INTERVIEWERS: So it wasn't strongly relevant for you within this conception?

LUCKMANN: Of course not, but that's obvious to anyone who reads the book. The concept of power mainly belongs to the category of institution-in my understanding. Now that you ask me-in institutions of power, regulating spontaneous violence, where one person is more "powerful" than the other, is sociologically not uninteresting. The main importance of the concept of power is in its institutional organization and its effects and its maintenance and its potential destruction. Most of the explanations of recruitment to milieus of violence are either partial explanations or no explanations at all.

\section{Theory of Action}

INTERVIEWERS: Let us shift to the next topic. We have a couple of questions referring to theory of action in general. The first question is: When you published your book Theorie des sozialen Handelns in 1992, the big debates on action dated back for some decades already. Was this publication a deliberate attempt to reanimate this discussion?

LUCKMANN: No. I think I can say that it wasn't a deliberate attempt. I didn't take any part in the polemics about rational action theory for example. I was guided by my own interests that I mentioned before, moving from the theory that is articulated in The Social Construction to the empirical, to the detailed study of how 
intersubjective action is constituted. Berger, on the other hand, is studying things on a larger scale. But he is also starting from the same point, from the same base. No, it wasn't a deliberate attempt to reignite the debate about the theory of action, although I was partly motivated by what I consider to be a not particularly adequate conception of action, Coleman for example and the German...

INTERVIEWERS: Hartmut Esser?

LUCKMANN: Esser, yes of course! He tries to take up some Schutzian concepts. In writing the book, I was really motivated by my own line of thinking with regard to the Schutzian theory of action. The motive was not to reignite the debate, but to make things clear for myself. In any case it's an introductory book, which I would call proto-sociological rather than sociological. But I thought it was useful to put things together in-what I hope-a clear way. Step by step, from an analysis of experience to the analysis of action, an analysis of interaction and the necessary constituent elements, to move from one level to the next. Beyond that I was teaching theory of action, that was one of my main courses, starting at the Graduate Faculty in New York, at the University of Frankfurt, and the University of Konstanz.

INTERVIEWERS: So I guess the next question has already been answered by what you said, but I pose it nevertheless. Was your theory of action specifically formulated against Rational Choice Theory or purely instrumentally rational conceptions of action?

LUCKMANN: No, not really. I had read a little bit of Coleman and Rational Choice Theory and quite a bit later some things of Esser, but that was not a polemic against that. A polemic looks different. I might have occasionally wanted to polemicize, but I never did.

INTERVIEWERS: How would you describe the main differences between your own approach and the seminal ones, like the one of Weber, for example?

LUCKMANN: I don't think that there are that many differences. I mean the main difference is in the method. Weber was formulating what he said were ideal types of action. I' $m$ a Weberian, as I said, from my early student days in sociology. And he is a very important influence on my thinking, but the categories in his theory of action don't impress me as very useful or systematic either. And methodologically his notion of what an ideal type is, which Schutz took over without much criticism, I can't accept as useful to describe what we are doing when we analyze empirical data from a very concrete level to a higher level of abstraction on which they are comparable to other empirical data from a different social milieu or different society. But the critique of Weber's categorization of action wasn't a polemic against Weber, this was a continuation of Schutzian thought.

INTERVIEWERS: Would you argue that your theory of action qualifies as a universal theoretical framework, or is it itself culturally determined?

LUCKMANN: Well, to start at the end. Of course it's culturally determined! I'll have to ask what you mean by universal theory. Everything social is culturally determined. Fetishism is culturally determined, physical science and astronomy are socially determined, culturally, if you want to use the term. If you take "determined" in a very weak sense, not in a physicalistic sense as it was used in nineteenth century physics where you could use "determined," "causally determined," in a much more ambitious way. So, they are either culturally 
determined in a weak way or they are not culturally determined if you take culturally determined in a literal way. As for a universal theory, we didn't have that kind of grand ambition. I think Parsons had. One can see that in some of his writings. Now, The Social Construction is a synthesis of classical thoughts, but I don't think that Berger and I were ambitious enough or rather vain enough to think that that would be grand universal theory of social science in general for the next 500 years, of course not. But if you meant something else by universal theory, then tell me.

INTERVIEWERS: Let us take Weber, for example. Weber says there's a kind of hierarchy between the ideal types of action, in the sense that rational action is kind of on the top of this hierarchy, because it's the clearest, the most evident type of action. One could argue that this understanding is culturally determined insofar as it corresponds to a rationalized society.

LUCKMANN: Oh, there is rational action in Siberian nomadic tribes of the nineteenth century. I said that I didn't quite accept the Weberian terminology and the theory of action. Rational action is a good example. Rational action is better described by Schutz and his "Choosing among Projects of Action" than by Weber. For Weber the theory of action was not all that important, that was an introduction to his main interests, to the sociology of religion, to the sociology of the economy, etc. So he thought he needed that and he did use it, it was not useless, but it is nothing that I think will stand for a long time-his theory of action. On the other hand, Schutz considered this an important part of his own work and so do I.

I think rational action is most—not all-action that humans do. We know usually what we can do in order to get something. If that is enough to define something as rational action, then most human action is rational. We usually know what we have to do in order to get where we want to get, if we know what we want. Of course, one can think of exceptions. Spontaneous, passion-loaded and -driven actions are outbursts more than actions toward an end and one can't call them rational, but they are still actions. On the other hand, that's not the main part; it's a small part of everyday life. The type of action that is involved there occurs, but not all that frequently in a reasonably well organized society. "What is a reasonably well organized society?" you wonder if you look at the news. If on the other hand rational action is only action that uses scientifically established ways to reach goals that are clearly defined, then there's very little of that. So, rational action again is a category that is not all that useful, unless you specify exactly what you mean by that. In Schutz' case I think that is achieved much better than in Weber's.

INTERVIEWERS: Okay. So maybe I combine two questions because I think they belong together. Which status do phenomena as creativity and improvisation have within your theory of action and how would you explain spontaneity following your theory of action?

LUCKMANN: My theory of action? Schutzian theory of action I think has not considered spontaneity specifically. I think spontaneity shifts away from the ordinary routines. Now the deliberate change of ordinary routines may be called creative, because it changes something, but the term creativity as used by most psychologists probably means something different. It has no particular place in my thinking. Whenever I started reading about it I soon gave up because I didn't think 
this was a proper way to approach it, but I didn't start thinking seriously about it myself, perhaps because I thought that I wouldn't get any further than the others.

INTERVIEWERS: The last question related to the theory of action is whether you would argue that - according to your theory of action - the project of action can be constituted within an interaction process?

LUCKMANN: Yes, definitely. The project of action is very rarely more than the starting point of action and even in "individual" action the project, unless it is fully routinized, rarely reaches its goal quite as it was intended. All sorts of things happen on the way, depending on the span of action. To become a top tennis star, for example, takes quite a few years. It usually starts at five in Florida, for example, and goes on to 19, 20 and doesn't end there and they are all sorts of interim changes and sub-projects of sub-projects that are linked to the main and final project. The degree of failure is enormous, of course. On the other hand a project such as "Oh, I'm thirsty, I'm going to get a glass of water" and getting up and getting a glass of water has a span of half a minute, depending on where the water is. But in these temperate zones with sufficient rain fall for all it's usually a matter of half a minute or lessunless the doorbell rings. So it depends on the span of action and that rarely changes on the way to get the glass of water, but it may change a lot on the way to becoming a tennis professional or getting a Ph.D.

\section{Sociology of Religion}

INTERVIEWERS We like to move on to the next thematic field, sociology of religion. What theoretical perspectives influenced your sociology of religion?

LUCKMANN: Theoretical perspectives. One general theoretical perspective was of course Durkheim, The Elementary Forms of the Religious Life, his much criticized book on Australian aboriginal religion. That was one influence. The other, that was not an influence, but should have been in retrospect, I mentioned it before, that's Robertson Smith, The Religion of the Semites. The third one, quite important, but in a different way was Weber again. Weber is everywhere. Although what I then attempted and what became The Invisible Religion is theoretically more directly linked to Durkheim than to Weber. Working on the Mayer project, I became familiar then with the theories in the field and also with the empirical work, particularly the Parish Studies by Father Joseph Fichter, Southern Parish and Social Relations in the Urban Parish, etc., which were formulated in the general framework of structural functionalism. They use fairly specific methods of investigation, which I adapted to the German church situation at that time and adapted for the study of German protestant parishes. Fichter's work didn't influence me theoretically, I don't think so. I myself had no theory when I started, nor did I have deeper knowledge of the research methods in the field. Then I became dissatisfied with the state of affairs in the theory of the sociology of religion in the following years. René König, he was then editor of the Kölner Zeitschrift für Soziologie und Sozialpsychologie, a fairly influential journal in German sociology, asked me to write a collective review of several books semi-theological, semisociological, and sociological, I think, four or five books. I started reading and 
became even more dissatisfied with the state of affairs. It was not Weberian, it was certainly not Durkheimian, not functionalist, nor structuralist. I was fairly criticalKönig published the review. And later when he heard of this, Bergsträsser, a professor in Freiburg, who kept inviting me for several years when I was still in New York, for summer visits and professorships, asked me "why do you merely complain, why don't you write something of your own?". I started writing a little booklet in German and then rewrote it for the English publication, with the unfortunate title The Invisible Religion. The title is not completely wrong, but it is misleading. It was not invented by me. In the German original it was called The Problem of Religion in Industrial Societies. The editor at Macmillan's, which published what became The Invisible Religion, said "that's a teutonic title, impossible". And I said "well I can't think of a better one," and then he suggested that. I said "well, it's alright". It led to many misunderstandings by people who read the title and didn't read the book, but thought they ought to vent their opinions on it. It doesn't matter to me now, but I was at first annoyed at the misreading. If they had read further than the title they would have noticed what was in the book. I suppose that was the answer to the first half of the question. Is there more to it what I have forgotten?

INTERVIEWERS: It was about the theoretical perspective which influenced your sociology of religion?

LUCKMANN: Well, as I said. I had no additional perspectives beyond Durkheim and beyond Weber, much later I read Robertson Smith. My teacher in the sociology of religion, Carl Mayer, was a Weberian and didn't influence my theoretical thinking beyond that. Eventually, I even managed to do some of my own thinking in those days.

INTERVIEWERS: The next question is about your own thinking and of your close colleague Peter L. Berger. While establishing a consensual standpoint in The Social Construction of Reality, you and Peter L. Berger chose different directions with regard to the sociology of religion. Why is this the case?

LUCKMANN: I'm not quite sure. I shall try to answer rather circumspectly. I think Berger originally accepted secularization theories. I didn't accept them from the beginning. I wrote an article once with the title which I will quote now, because it answers the question "Secularization-A Contemporary Myth". Berger had much theological training, I had none. Incidentally, I am a catholic and Berger is protestant. That might have made a difference. He was more influenced by Rudolf Otto than I was. We both read some of the same things in the "classical" sociology of religion like Joachim Wach and so forth and came to different conclusions. His sociology of religion is definitely not Durkheimian, mine is. Both of us are Weberians at the same time on a different level, but on the elementary level of what is religion and how to approach it sociologically, we differ. In our work there is no serious discussion of religion as a social construction. That was not our topic. Later on we collaborated on other things, but never on religion, for obvious reasons. We agreed to have different positions. He has changed his stance of theory of secularization to a considerable extent, but the starting point was as I described.

INTERVIEWERS: In a publication from 1990 you were talking about "shrinking transcendence," stating that "modern social constructions of religious significance 
shifted away from the great other-worldly transcendences". Do you regard it as possible that the "great transcendences" might disappear completely in a historical process?

LUCKMANN: No. Or at least it is extremely unlikely. I'll say why I said no. No, unless there's a transformation of the human condition, a basic transformation, much more basic than the one from the hunters and gatherers of 10,000 years ago to American capitalist society. Now it's not impossible, if the earth survives, that the human species will mutate into a different species. And then God knows what will happen. Now, you see, one has to indulge in a rather wild speculation before one can get to a positive answer to your question. As long as things remain roughly the same as in the past, let's say 20,000 years, I doubt that religion of great transcendencies will disappear completely, but may shrink considerably. If people stop dying, for example, then perhaps. It is the death of the other person close to you rather than one's own death that is more important in this context. If that disappears from human experience, it will be a different species.

INTERVIEWERS: The major thesis you formulated in your Invisible Religion in 1967 claims that religion retreats from the public sphere and increasingly becomes privatized. Today, when considering the public staging of church events like papal visits, and their huge representation in the media, would you formulate your thesis differently?

LUCKMANN: The thesis of a shift from the public to the private?

INTERVIEWERS: Yes.

LUCKMANN: Perhaps to a certain extent, but it's not the papal visit with mass attendance in a soccer stadium or on St. Peters Square that is pertinent here. True, it is a kind of participation in a public event. It's a lot of fun because there are a lot of other people around and they are all waving little flags. There are mixed motives. Organized religion continues to be an unimportant thing in the public sphere, just as soccer events are unimportant in that sense. Perhaps that is not a quite proper comparison, but it shows the point that I want to make. Contemporary Western institutions were formed in Christian societies, and those are the ones that define much of the public sphere. Now organized religion is without influence in all European societies. Mutatis mutandis, it's slightly different, but basically still the same in the United States. It's still different in Latin America, but not all that different either. So I think the basic point of the retreat from the public sphere, the forced retreat-it didn't go voluntarily-from the public sphere still holds for this type of society and that's the only kind of society for which I formulated this assumption. I didn't know and still don't know enough about Islam, although I've been reading up a little more than I did 50 or at least 40 years ago. The developments in Islam are for me difficult to explain. But I find it difficult to explain how Catholicism produced the Grand Inquisition, which is even farther from the teachings of the sayings of Jesus as reported in the gospels as is ISIS from Mohammed's Koran. I suppose I ought to know more about the latter in order to be saying that.

INTERVIEWERS: In going back to the anthropological foundations of religiosity, you widened the sociological concept of religion. In this context, you argued that religion fulfills a necessary function within society. This idea could be 
interpreted as an objection to the Marxian thesis on the disappearance of religion. Would you share this interpretation?

LUCKMANN: Share with Marx? No, I don't share it with Marx! But Marx didn't think of the same thing than I thought with this. Marx thought of the disappearance first of organized religion and then of particular conceptions of another world. He was of course a materialist. I don't share that view. Is there more to say? In my own view, religion is a universal, but differs in how it is organized socially as well as in the contents of the world view that organizes thinking from disparate strands of thought that arise in different kinds of everyday action. Religion connects them into what approximates a meaningful whole. In one little article that we talked about yesterday, "The Boundaries of the Social World," I tried to show that animism is a perfectly normal form of organizing sense for a certain type of society although it's not mine, nor yours I take it. But for Marx, if he ever mentioned animism, it was an aberration of the human mind, just as any religion. He doesn't have a good materialistic explanation for why the aberrations occur. Well, there is an attempt of an explanation, but it doesn't seem to be adequate.

\section{Language, Communication, and Genre Analysis}

INTERVIEWERS: One of the central concepts in your reflections on language and communication is the one of typification. You mentioned on different occasions that your notion of types is different from the one of Max Weber. Could you please tell us more about this difference?

LUCKMANN: Well, I don't think that ideal types are particularly useful. If I recall it correctly, Weber's ideal type takes certain features from a concrete social phenomenon, exaggerates them in the abstract, as it were, as an ideal type, and neglects others. That's why he thinks it's not a real type, because it neglects other features, which are concretely present in the phenomenon. That sounds quite reasonable, but I think it doesn't acknowledge that all types abstract from concrete features. The type by definition looks at certain features and neglects some others. Well, that is perhaps an unimportant difference, but I think even the label "ideal type" is unfortunate even though it is much accepted by sociologists even today. Weber considered the ideal type as a main analytic concept, but for me, either they are types of sociation or they are not types of sociation. Why ideal? What's ideal about the "Gemeinschaft"? What's ideal about the "Gesellschaft"? These are highly abstract features of categories, of a typification of sociation, of social organization.

INTERVIEWERS: How would you describe the connection between your reflections on a sociology of language of the late 1970s and your theory of communicative genres you developed decades later?

LUCKMANN: Again, I have to look around in my own recollection so that I can formulate an answer adequately. My thinking on language was influenced first during my studies in linguistics. I studied linguistics in Vienna for several semesters, comparative linguistics, but not much beyond that, so I'm not a trained linguist at all. But I had an inkling of what was happening in linguistics and I read 
much of linguistics later on. That was one background influence. Another one was a book by the Austrian philosopher Friedrich Kainz, who wrote a compendium on language, which is highly informative. I didn't read it from the beginning to the end, but I gathered more than a few bits and pieces of information about linguistic theories, as well about the philosophies of language. And then it was Husserl's theory of signs, as developed by Schutz, that seemed to me a good basis to start from.

I didn't formulate a sociology of language in those days, in the 60 s or 70 s, but I was reading quite a bit on that, and did some thinking on language. Reading sociology of language of these days, I became dissatisfied with what was happening both in the States and in France, and elsewhere. I don't recall any German sociology of language of that period. But I had other work to do and other interests to follow in those days, so this was a subsidiary interest that never broke off completely from my early student days.

The theory of signs was still rather-let me use a category I don't like, but I can't think of a better one-a static theory. René König again pops up here. He asked me to contribute an article on the sociology of language for his Handbook of Empirical Social Research. That book had two editions. For the first edition, I read hundreds of books and many hundreds of articles. For a handbook paper you have to read everything, whether it is good, bad, or idiotic. I never wrote another handbook article afterwards. It was hard work. I mention it because at that time I did not know well enough the works both in the ethnography of speaking and the ethnography of language, that is Hymes and Gumperz, nor Gumperz's other work. Nor did I really know conversational analysis, a particular form of sequential analysis, nor any other variety of sequential analysis. That changed in the 8 or 9 years between the first and the second edition. I re-wrote the article for the second edition completely. I considered all that I had read in the meantime. And that was for me the starting point of a rather new way of thinking about language that centered on the processes of communication rather than on its contents as such. And then I more or less coincidentally got in touch with literary scholars in Konstanz, taking up the notion of genre to describe certain models of ordinary and extra-ordinary communication. And then I even got a few projects going, with some very good assistants. I already mentioned Bergmann, who influenced my knowledge of the method of sequential analysis.

INTERVIEWERS: Some scholars observe a shift in your theoretical reflections in the last decades. They argue that the issue of communication has become more and more important in your work, and in 2005 you yourself spoke of a "communicative construction of reality" instead of a "social construction of reality". Would you agree that there is such a development or is it simply two sides of the same coin?

LUCKMANN: Too bad that I don't know what other people wrote about me. My vanity would be interested in that, but not sufficiently to search for it. If they saw a real change, I would disagree. The change that was involved I already mentioned. That can be discerned in the difference of my contribution to the first and the second edition of König's Handbook. That shows a certain change already. And the main change came with the empirical work. When I started with that I was already 
theoretically influenced by the concept of genre, applying it to sequential analysis. The concept of genre is a good concept in the theory of communication which was applicable to the empirical analysis of communicative processes.

Beyond that I don't think there was much of a change. Berger and I always thought that the social construction of reality was basically communicative, although we perhaps didn't say so. I used the term "communicative construction of reality". The term isn't mine, it's from Knoblauch. I don't know whether he invented it, but he used the term "communicative construction" in the title of his book. I don't attach much importance to the apparent shift from "social" to "communicative". Of course not all social interaction is communicative in a narrower sense. My interest was merely in non-verbal and verbal communication, rather than in what merely presupposes indirect communication, like building bridges. So unless you call all social interaction communicative-which I think is true in a wider sense of the term - it is not indefensible to define social construction as a communicative process or as the result of communicative processes.

INTERVIEWERS: You developed the idea that communicative genres solve specific problems of a society or a culture. Could you explain us how this idea was created?

LUCKMANN: The idea is Durkheim's. Durkheim seems to pop up more often than I thought he would. Durkheim's conception of a social fact and of a social institution is in the background. Institutions solve social problems by regulating social interaction. These are not Durkheimian terms, but that's what is meant, I think. Institution is the general term for a form of social organization that seeks a certain degree of permanence and that exercises some form of constraint, not necessarily force, but constraint may include force. That's a general term. For the specifically communicative interaction which uses a sign system, verbal or nonverbal, there is obviously something like an "institution," structures that exercise a certain degree of constraint on what you say, when you say it, and how you say it. And that, I think, is what communicative genres do.

Now that's not an everyday but an analytic term. The everyday term genre applies mainly to literature. Everybody knows what a novel is, or a poem, or a sermon-well, no, one doesn't think of sermons as genres in ordinary life. Genres don't solve social problems in general. They solve specifically communicative problems that arise in social interaction and social communication by providing models of how to say things. A sermon is a good point in this case. There are sermons in everyday life, non-religious sermons, which have pretty much the structure of a sermon, an appeal, a pointing out of the terrible consequences of a particular type of action, for example smoking, an appeal to change. This is the basic structure, seen in prophetic speech in the Old Testament. Conversion stories are another genre. Religious or secular, as in Alcoholics Anonymous testimonies, conversion stories provide models, and when you record conversion stories you will see that they share many common structural elements. Those who tell conversion stories follow that model, although they didn't learn genre theory, maybe didn't even read all that many conversion stories or heard them. And it's not easy to talk about conversion unless you have some sort of model that you follow and that you can deviate from up to a certain extent. In some circumstances you can start using a 
genre and then abandon it. Also there are ironic forms of genre. You use a genre, but not in its original sense, in an ironic sense, etc.

Coming back to the original question, the concept of genre refers to Durkheim's idea of social fact and of social institution as solving social problems, and it applies this idea to communicative interaction.

INTERVIEWERS: Your increasing occupation with language and communication in the 1970s coincides with your move to the University of Konstanz. Has this to do with the academic environment you came upon in Konstanz?

LUCKMANN: I'm not sure. Probably yes, up to a point. I was always interested, from my student days on, in language, even for biographical reasons-I grew up bilingually with English as my third language - not only for scholarly reasons. That interest didn't fill my time completely, as I was occupied with many other things, both for theoretical and for practical reasons. In order to have a job, for example as a teacher of sociology, I had to teach many other things, although I tried to smuggle my interests into my own teaching in all the universities I taught at, starting at Hobart College, the Graduate Faculty, and then in Frankfurt and in Konstanz. I remained interested, but I didn't write on it and I didn't think systematically of it.

My systematic examination of language started later and it may coincide with some aspects of the academic environment in Konstanz. One aspect I mentioned already is that I had contact with scholars in literature in Konstanz, teaching English, Romance, Slavic, and other literatures and classical studies; Hans Robert Jauss, Wolfgang Iser, Renate Lachmann, Manfred Fuhrmann, for example. At that time, genre was not a popular term in literary scholarship, yet I took up the term genre, in this environment. One of the reasons that I went to Konstanz was this milieu in literary scholarship and history. Many of these colleagues were involved in an interdisciplinary project called "Poetik und Hermeneutik". I was invited, not as a permanent member, but fairly frequently. Topics of language, of communication were regularly treated in these annual meetings.

INTERVIEWERS: To come to the final question: Is there a book you would have liked to write, but never had the chance to? What would have been the topic?

LUCKMANN: I don't know about a book. But I know what I had planned or wanted to work on, and I didn't. They are several, not one. Many years ago, I thought that one ought to write a sociology of sexuality because there isn't a good one. I never started seriously on it, collecting material or even thinking about it, and the diffuse sense of inadequacy of what others in sociology said about it is not enough to get me started.

Another project for which I had collected quite a bit of material was to write a sociology of ignorance and stupidity. This too is closely related to categories or phenomena that are not usually considered or treated in sociology. Perhaps the attempt to think about it seriously or write about it, would meet with serious disapproval from most sociologists today. But I collected a lot of material, mainly clippings from the newspapers, but from other sources also, yet I never got beyond that.

The third thing was closer to completion and failed in the end. That is a project that I still had at the university, after retiring from teaching, a study of everyday aesthetic experience and everyday aesthetic communication. That was part of a 
group of projects gathered under the title of "Anthropology and Literature". It was financed by the German Science Foundation. And I had a little project for which I got the funding for two assistants and for some of the material we needed. We worked on it for several years and we had fascinating material in part, for example on school children acting at interviewing. The girls were usually interviewing a top mannequin, and the boys were usually interviewing soccer stars. You could see that genres were involved there, highly aestheticized genres. There was fun involved, there was a certain beauty in the performances-especially of the girls, doing interviews with other school girls as if they were TV-interviewers and the other one was a top model. Other material consisted of initiation ceremonies for printers (still surviving in Mainz), moving from apprenticeship to the next status in the hierarchy of printing. We also video-recorded several weddings. Weddings have a function that isn't aesthetic. They have other purposes and people don't go there because it's beautiful or not go because it is not. But it has a strong aesthetic component, just as funerals for example. I can speak of a beautiful funeral, a beautiful wedding. It was the aesthetic components which we tried to analyze through the recordings. It's a pity that the project didn't come to an end for reasons I do not want to discuss. I took the data along and thought maybe I would take it up by myself later again. But then all sorts of things intervened and I never continued seriously with it. That I regret more than the other two projects that I didn't do. Although, the sociology of stupidity and ignorance would be quite interesting. And there is enormous material which is not surprising because there is a lot stupidity around.

INTERVIEWERS: Thank you very much.

LUCKMANN: Not at all. 